\title{
Effects of superovulation, embryo recovery, culture system and embryo transfer on development of rabbit embryos in vivo and in vitro
}

\author{
E. W. Carney and R. H. Foote \\ Department of Animal Science, Cornell University, Ithaca, New York 14853-4801, USA
}

\begin{abstract}
Summary. Uninterrupted development of rabbit embryos in vivo was studied in 7 superovulated and 7 normally ovulating (GnRH-treated) does, while another 7 does were superovulated and 1-cell embryos were collected from them at $19 \mathrm{~h}$ after LH to compare development in vivo and in vitro. Embryos from the last group were either cultured in the presence or absence of rabbit oviduct epithelial cells for $65 \mathrm{~h}$ in Medium 199, or were immediately transferred to recipients. At $84 \mathrm{~h}$ after $\mathrm{LH}$ or $\mathrm{GnRH}$, blastomere number, embryo volume and stage of development were assessed for all embryos.

Intrazonal embryo volumes were significantly reduced in embryos recovered from superovulated donors. Superovulation also had a negative effect on embryo cell numbers. However, this reduction was more severe in embryos remaining in vivo in superovulated donors until $84 \mathrm{~h}$ after $\mathrm{LH}$ than it was in embryos transferred to nonsuperovulated recipients at the 1 -cell stage $(19 \mathrm{~h}$ after $\mathrm{LH})$. The embryo recovery procedure apparently caused little harm to the embryos, except that the mucin layer on flushed and immediately transferred embryos was significantly thinner than that of embryos residing continuously in vivo. Co-culture with rabbit oviduct epithelial cells resulted in improved development in vitro, but this development was still significantly retarded compared with embryos developing in vivo.
\end{abstract}

Kelwords: rabbit; embryo culture; superovulation; embryo transfer; co-culture

\section{Introduction}

The development of preimplantation rabbit embryos in vivo is characterized by a very rapid cell division rate and increase in mass during the first few days after conception. The length of the cell cycle averages only $8-9 \mathrm{~h}$ during this period, with the embryo just before implantation on Day 6 consisting of approximately 80000 cells (Daniel, 1964) and reaching a diameter of $3-4 \mathrm{~mm}$ (Alliston \& Pardee, 1973).

Despite much work to define amino acid, vitamin, protein, and other nutrient requirements of rabbit embryos in vitro, development in culture is retarded compared to that observed in vivo (Seidel, 1976; Binkerd \& Anderson, 1979; Fischer, 1987; Kane, 1987). As further refinements in culture techniques are made, the question arises as to what constitutes appropriate criteria for measuring improvements in embryo growth rate. The few quantitative data on early embryo development in the rabbit only describe development following natural matings (Adams, 1958; Daniel, 1964; Alliston \& Pardee, 1973), yet most embryos used for culture are recovered from superovulated famales. Also, few specific controlled comparisons have been made of the effects of flushing oviducts and uteri or of washing embryos in simple salt solutions on embryo development. Superovulation and embryo flushing both could have a negative impact on subsequent development. Therefore, it is important to partition these possible effects from culture effects when comparing growth rates in vitro and in vivo and to design protocols that avoid or minimize these potential effects. 
This study was designed to compare early development of embryos (a) remaining undisturbed in the oviducts of normal and (b) superovulated rabbits, or after (c) flushing and culture or (d) flushing and immediate transfer of embryos to pseudopregnant recipient does. Embryo volume, number of blastomeres and morphology were measured to provide a quantitative assessment of the effect of these procedures on early rabbit embryo development. These data were used as a baseline to compare development of rabbit 1-cell embryos co-cultured with rabbit oviduct epithelial cells.

\section{Materials and Methods}

Animals and experimental design. Twenty-five sexually mature Dutch-belted rabbits, housed individually under constant environmental conditions ( $12 \mathrm{~h}$ light: $12 \mathrm{~h}$ dark, lights on at $07: 00 \mathrm{~h}, 17-22^{\circ} \mathrm{C}$ ), were used to provide embryos which were treated as shown in Fig. 1. Development of embryos left undisturbed in vivo was assessed by administering $1.2 \mu \mathrm{g}$ buserelin acetate, a gonadotrophin-releasing hormone $(\mathrm{GnRH})$ analogue (Receptal ${ }^{\odot}$, Hoechst-Roussel, Somerville, NJ, USA), intramuscularly to 7 rabbits to induce a physiological number of ovulations. Receptal will be hereafter referred to as $\mathrm{GnRH}$. This was immediately followed by artificial insemination with $0 \cdot 1 \mathrm{ml}$ fresh ejaculated semen from a male of proven fertility. Embryo development was then allowed to proceed undisturbed until $84 \mathrm{~h}$ after GnRH.
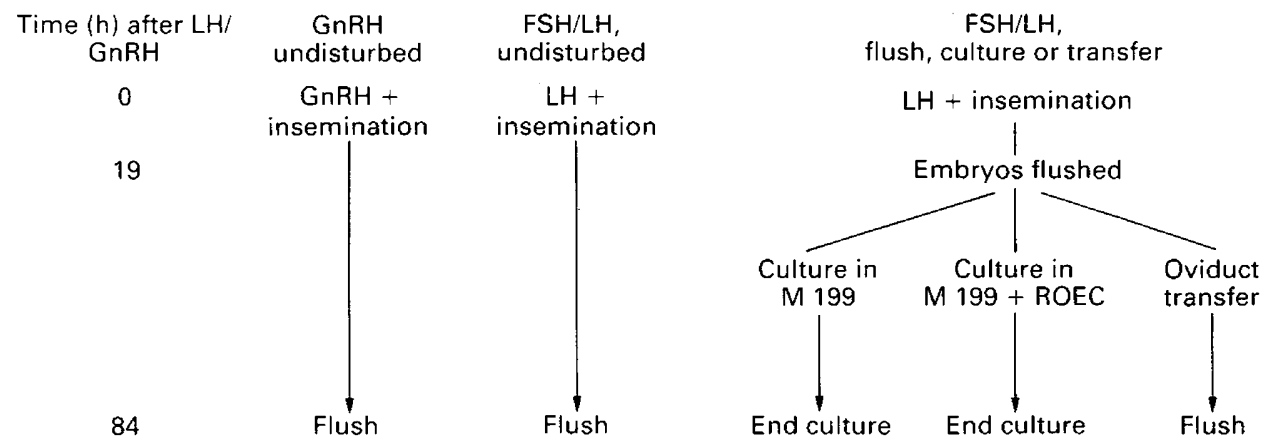

Determine stage, measure diameter, fix, stain and count nuclei

Fig. 1. Flow chart of experimental design. ROEC = rabbit oviducal epithelial cells.

A parallel study of the effect of superovulation on embryo development was done in 7 other does which received FSH-P (Schering, Kenilworth, NJ, USA) and LH (Vetrepharm, London, Ontario, Canada) as previously described (Kennelly \& Foote, 1965). These rabbits were also inseminated at the time of LH injection, and embryo development was allowed to proceed undisturbed until $84 \mathrm{~h}$ after $\mathrm{LH}$.

Does $(\mathrm{N}=7)$ in a third group were superovulated and inseminated and their 1-cell embryos were recovered at $19 \mathrm{~h}$ after $\mathrm{LH}$ to compare development in vitro as well as following immediate transfer to recipients. These 1 -cell embryos were surgically collected by retrograde flushing of oviducts (Kennelly \& Foote, 1965) with 2-3 ml phosphate buffered saline (PBS; GIBCO, Grand Island, NY, USA) containing $1 \mathrm{mg}$ polyvinyl alcohol $/ \mathrm{ml}$ and $5 \%(\mathrm{v} / \mathrm{v})$ antibiotic/antimycotic solution (GIBCO). Anaesthesia was induced by first administering an intramuscular injection of a mixture of $30 \mathrm{mg}$ xylazine (Rompun ${ }^{\oplus}$, Butler, Columbus, OH, USA) and I mg acepromazine maleate (TechAmerica, Elwood, KS, USA) followed 5-10 min later with a similar injection of $150 \mathrm{mg}$ ketamine hydrochloride (Ketaset ${ }^{\circledR}$, Aveco, Fort Dodge, IA, USA).

After collection, the embryos were washed through two changes of PBS and any abnormal embryos or ova, as judged by the presence of a granular cytoplasm, irregular shape, or excessively thick mucin layer, were discarded. The effect of the embryo recovery procedure was examined by immediately transferring one-third of these embryos (average 5.7 embryos/transfer) in 3-10 $\mu$ l PBS to the oviducal ampullae of recipient does which had been made synchronously pseudopregnant by injection with GnRH. Each recipient hosted embryos from 2 different donors in opposite oviducts for $65 \mathrm{~h}$. The interval between flushing of donor does and preparation of recipients for transfer averaged $36 \mathrm{~min}$ (range 27-50), during which time the embryos were held in PBS at room temperature.

The remaining one-cell embryos were similarly held, equally divided, and placed into culture for $65 \mathrm{~h}$ at $39^{\circ} \mathrm{C}$ in Medium 199 in the absence or presence of monolayers of rabbit oviduct epithelial cells. This design allowed for a comparison of early embryo development in vitro and in vivo, while controlling for the effects of superovulation and embryo recovery. 
Evaluation of embryo development. Approximately $84 \mathrm{~h}$ following $\mathrm{GnRH}(84 \cdot 3 \pm 0.3 \mathrm{~h}$ after $\mathrm{GnRH})$ or LH $(84 \pm 0.1 \mathrm{~h}$ after $\mathrm{LH})$, rabbits containing native or transferred embryos were killed by intravenous injection of sodium thiamylal (Surita! ${ }^{\oplus}$, Parke-Davis, Morris Plains, NJ, USA) and their oviducts and uteri were immediately flushed with PBS. This time point, which was about $72-74 \mathrm{~h}$ after ovulation, was chosen to approximate the time when rabbit embryos normally leave the oviduct and enter the uterus (Adams 1958; Hodgson \& Pauerstein, 1976). Dimensions of the intrazonal diameter, thickness of the mucin coat, and total diameter of the embryo with its coverings of zona pellucida and mucin layer (Fig. 2) were quickly measured at room temperature using an inverted microscope fitted with a calibrated eyepiece micrometer. Immediately after measurement, development was terminated by the addition of formaldehyde. At this same time, embryos which had been in culture for $65 \mathrm{~h}$ were similarly measured and fixed.

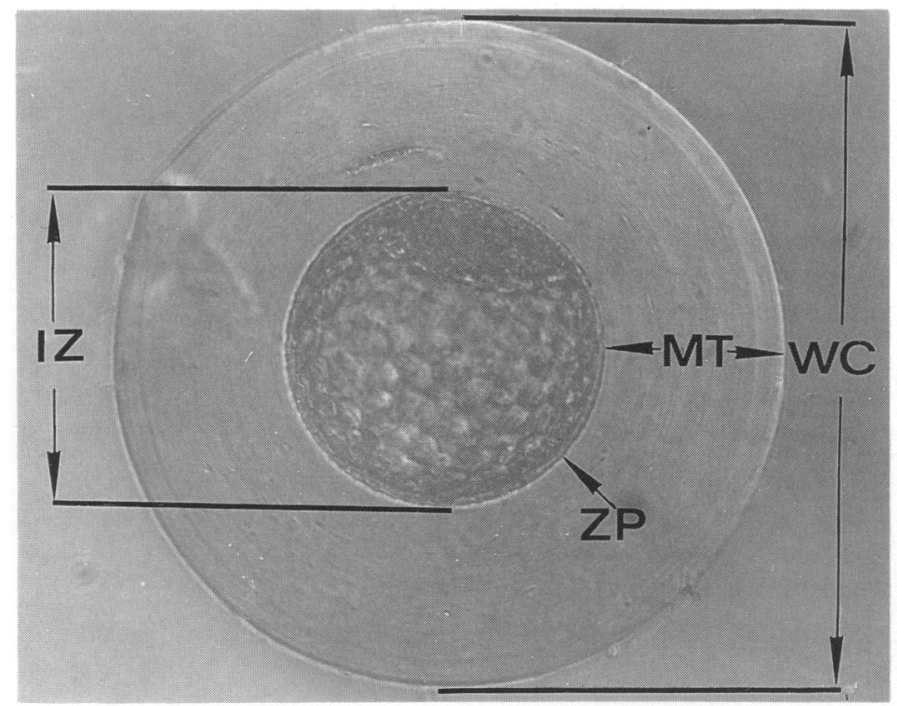

Fig. 2. Measurement of embryo dimensions. $Z P=$ zona pellucida, $M T=$ mucin coat thickness, $\mathrm{IZ}=$ intrazonal diameter, $\mathrm{WC}=$ diameter of the embryo with its coverings.

Blastocysts were classified as 'expanding' when their intrazonal diameters had equalled or exceeded $134 \mu \mathrm{m}$, this being a point where embryos had clearly thinned zonae pellucidae and mucin layers. Embryo volume was calculated from the diameter (D), using the formula Volume $=1 / 6 \pi \mathrm{D}^{3}$, with the assumption that the embryos were spherical in shape. The number of blastomeres per embryo was determined by staining embryos for 3 min with the DNA-specific fluorochrome Hoechst 33342, using a 3-min pre-stain with $0.1 \%$ trypan blue to quench fluorescence of sperm heads embedded in the mucin coat (Pursel et al., 1985). Accurate counting of nuclei at $\times 500-800$ magnification was facilitated by the use of an ocular grid. The presence of pycnotic nuclei and mitotic figures was also noted.

Culture conditions. Primary cultures of rabbit oviduct epithelial cells were obtained by a modification of methods described by Black et al. (1985) and Fairchild (1987). Oviducts were removed from oestrous rabbits and filled with a solution containing $2 \cdot 5 \%$ pancreatin (GIBCO) and $0.5 \%$ trypsin (1:250, Sigma, St Louis, MO, USA), then incubated for $2 \mathrm{~h}$ at $4^{\circ} \mathrm{C}$ and $1 \mathrm{~h}$ at room temperature $\left(21-23^{\circ} \mathrm{C}\right)$. The epithelial cells were then flushed from the enzyme-treated oviducts, washed several times in PBS and plated into 4-well dishes (Nunclon, Thomas Scientific, Swedsboro, NJ, USA) containing $450 \mu \mathrm{l}$ culture medium/well. This procedure yielded ciliated and non-ciliated oviduct epithelial cells essentially free of stromal cell contamination.

After 4 days, culture media and unattached cells were removed and replaced with fresh media and 1-cell embryos (collected $19 \mathrm{~h}$ after LH) were added. Control wells were identical to co-culture wells except that epithelial cells were not present. These wells had also been set up 4 days previously and incubated with culture media to ensure maximum parallelism between control and co-culture treatments.

The culture medium was serum-free Medium 199 containing Earle's salts (GIBCO, Cat. No. 400-1 100EB) and was supplemented with $5 \mu \mathrm{g}$ insulin $/ \mathrm{ml}, 5 \mu \mathrm{g}$ transferrin $/ \mathrm{ml}, 5 \mathrm{ng}$ selenium/ml (CR-ITS Premix, Collaborative Research, Bedford, MA, USA), and $10 \mathrm{ng}$ epidermal growth factor $/ \mathrm{ml}$ (Collaborative Research) as described by Black et al. (1985). Then Fraction V bovine serum albumin (Sigma, Cat. No. A-9647), $15 \mathrm{mg} / \mathrm{ml}$, was added to the medium when it was changed at the time of embryo addition on Day 4 . The $\mathrm{pH}$ of the culture medium was $7 \cdot 3-7 \cdot 4$ after equilibration in an humidified atmosphere of $5 \% \mathrm{CO}_{2}$ in air at $39^{\circ} \mathrm{C}$. Embryos were cultured under these conditions for $65 \mathrm{~h}$, and the embryos then $84 \mathrm{~h}$ old ( $19 \mathrm{~h}$ precollection $+65 \mathrm{~h}$ culture), were measured and fixed.

Statistical analysis. Data in Table 2 were obtained from 21 different rabbits ( 7 per treatment) and treatments were compared using a series of unpaired $t$ tests. All data for blastomere number intrazonal volume and volume of the 
embryo with its coverings were transformed logarithmically, while proportional data were subjected to the angular transformation (Zar, 1984). The raw data were used to analyse mucin thickness.

The data summarized in Table 3 were obtained from a single group of 7 rabbits. One-cell embryos were randomly assigned by donor to each of the 3 treatment groups. Any 1-cell embryos which were later determined by nuclear staining to be unfertilized ova were excluded from the analyses. Two-way analysis of variance was performed, using the general linear models procedure of the Statistical Analysis System (SAS Institute, Cary, NC), with individual means compared using protected Fischer's least significant difference tests (Snedecor \& Cochran, 1980). The value entered into each cell of the ANOVA contingency table was the average of embryos from a single embryo donor for a given treatment group. Therefore, means shown in Table 3 were calculated as the mean of these values, not as the mean of individual embryos used for the $t$ tests in Table 2.

\section{Results}

\section{General}

The effects of superovulation treatment on ovulation points and embryo recovery rates, are shown in Table 1. The difference in number of ovulations was expected as a result of FSH treatment.

Table 1. Embryo recovery rates at $84 \mathrm{~h}$ after $\mathrm{GnRH} / \mathrm{LH}$ in normally ovulating does $(\mathrm{GnRH})$, in superovulated does $(\mathrm{FSH} / \mathrm{LH})$, or superovulated does providing embryos for culture or immediate transfer

\begin{tabular}{|c|c|c|c|}
\hline & \multicolumn{3}{|c|}{ Donor and embryo treatment } \\
\hline & \multirow{2}{*}{$\frac{\text { GnRH }}{\text { Undisturbed }}$} & \multicolumn{2}{|c|}{ FSH $/$ LH } \\
\hline & & Undisturbed & Flush/transfer* \\
\hline Ovulations per embryo donor & $7 \cdot 7^{\mathrm{a}}$ & $25 \cdot 7^{\mathrm{b}}$ & $19 \cdot 7^{\mathrm{b}}$ \\
\hline $\begin{array}{l}\text { Embryos recovered per rabbit } \\
(84 \mathrm{~h} \text { after GnRH or LH) }\end{array}$ & $6 \cdot 1$ & $19 \cdot 9$ & $2 \cdot 9$ \\
\hline$\%$ embryos recovered & $87 \cdot 3^{\mathrm{a}}$ & $72 \cdot 3^{a \cdot b}$ & $55 \cdot 0^{\mathrm{b}}$ \\
\hline
\end{tabular}

*Embryos flushed from superovulated donors and transferred to non-superovulated recipients at $19 \mathrm{~h}$ after $\mathrm{LH}$. The mean number of embryos transferred to each oviduct was 5.7 .

${ }^{\mathrm{a}, \mathrm{b}}$ Significantly different $(P<0.05)$.

\section{Effect of superovulation}

Data on development of embryos in non-superovulated and superovulated rabbits are shown in Table 2. Significantly fewer cell numbers $(P=0.002)$ and smaller intrazonal volumes $(P=0.02)$ were observed in embryos recovered from superovulated rabbits than in controls, but no significant effect of superovulation was found on other characteristics evaluated (Table 2). In both treatments, only $6 \%$ of the embryos were visibly abnormal, as judged by the presence of blastomeres extruded into the perivitelline space or embryos having a grossly irregular morphology.

\section{Effect of embryo recovery}

The most obvious effect of embryo flushing at $19 \mathrm{~h}$ after $\mathrm{LH}$ was the thinner mucin layer and smaller embryo volume with coverings $(P<0.005$, Table 2$)$ when compared with embryos remaining undisturbed in vivo. On the other hand, cell numbers and the percentage of embryos forming blastocysts or expanded blastocysts were not significantly affected. Intrazonal volumes were similar to those observed in the undisturbed, superovulated group, but were significantly $(P<0.05)$ lower than in the undisturbed, GnRH-treated group. 
Table 2. Development at $84 \mathrm{~h}$ after $\mathrm{GnRH} / \mathrm{LH}$ of embryos residing continuously in control or superovulated females or after flushing and immediate transfer of 1-cell embryos to recipients

\begin{tabular}{|c|c|c|c|}
\hline & \multicolumn{3}{|c|}{ Donor and embryo treatment } \\
\hline & \multirow{2}{*}{$\begin{array}{c}\text { GnRH } \\
\text { (Undisturbed) }\end{array}$} & \multicolumn{2}{|c|}{ FSH/LH } \\
\hline & & Undisturbed & Flush/transfer \\
\hline No. of embryos evaluated & 36 & $70^{*}$ & 20 \\
\hline Blastocysts, $\%$ & $83^{a} \pm 9$ & $72^{a} \pm 11$ & $68^{\mathrm{a}} \pm 18$ \\
\hline Expanding blastocysts, \% & $66^{\mathrm{a}} \pm 16$ & $60^{\mathrm{a}} \pm 11$ & $56^{\mathrm{a}} \pm 19$ \\
\hline Cell number & $242^{\mathrm{a}} \pm 14$ & $187^{b} \pm 9$ & $211^{a, b} \pm 26$ \\
\hline Intrazonal volume (nl) & $262^{\mathrm{a}} \pm 31$ & $177^{b} \pm 14$ & $168^{b} \pm 24$ \\
\hline Volume with coverings ( $\mathrm{nl}$ ) & $2699^{a} \pm 173$ & $2421^{a} \pm 139$ & $1714^{b} \pm 197$ \\
\hline Mucin thickness $(\mu \mathrm{m})$ & $90^{\mathrm{a}} \pm 4$ & $88^{\mathrm{a}} \pm 3$ & $66^{\mathrm{b}} \pm 6$ \\
\hline
\end{tabular}

Values shown are means \pm s.e.m.

*Ten embryos per donor were randomly chosen for evaluation.

a, bignificantly different $(P<0 \cdot 05)$.

\section{Effect of co-culture}

Rabbit 1-cell embryos co-cultured with rabbit oviduct epithelial cells achieved significantly $(P<0.005)$ higher cell numbers than did embryos grown in Medium 199 without such cells (Table 3). After $65 \mathrm{~h}$, co-cultured embryos were already an average of one cell division cycle ahead of embryos in culture medium alone, or, viewed from another perspective, had an average cell cycle time which was nearly $2 \mathrm{~h}$ shorter than that of embryos cultured without epithelial cells (Fig. 3).

Table 3. Comparison of development at $84 \mathrm{~h}$ after $\mathrm{LH}$ of embryos recovered from superovulated donors grown in vivo and in vitro

\begin{tabular}{|c|c|c|c|}
\hline & \multicolumn{3}{|c|}{ Embryo development } \\
\hline & \multicolumn{2}{|r|}{ In vitro } & \multirow{2}{*}{$\frac{\text { In vivo }}{\text { Flush/transfer }}$} \\
\hline & M 199 & M $199+$ ROEC $*$ & \\
\hline No. of embryos & 38 & 37 & $20 \dagger$ \\
\hline Blastocysts, $\%$ & $20^{\mathrm{a}} \pm 10$ & $35^{\mathrm{a}} \pm 11$ & $68^{a} \pm 18$ \\
\hline Expanding blastocysts, \% & $0^{a} \pm 0$ & $19^{a} \pm 9$ & $56^{b} \pm 19$ \\
\hline Cell number & $46^{\mathrm{a}} \pm 11$ & $113^{b} \pm 17$ & $195^{b} \pm 37$ \\
\hline Intrazonal volume (nl) & $61^{a} \pm 4$ & $81^{a} \pm 8$ & $178^{b} \pm 46$ \\
\hline Volume with coverings ( $\mathrm{nl}$ ) & $165^{a} \pm 5$ & $177^{2} \pm 11$ & $1535^{\mathrm{b}} \pm 300$ \\
\hline Mucin thickness $(\mu \mathrm{m})$ & $2^{\mathrm{a}} \pm 0$ & $2^{a} \pm 0$ & $60^{b} \pm 10$ \\
\hline
\end{tabular}

Values shown are means \pm s.e.m.

*Rabbit oviduct epithelial cells.

†Represents same embryos as in Table 2 . However, means shown were calculated by donor, as done in the ANOVA.

${ }^{\text {a.b }}$ Significantly different $(P<0.05)$.

Other criteria measured were not affected by co-culture (Table 3). The oviduct epithelial cells did not appear to release mucin in vitro, as there was no further accumulation of mucin on co-cultured embryos. 


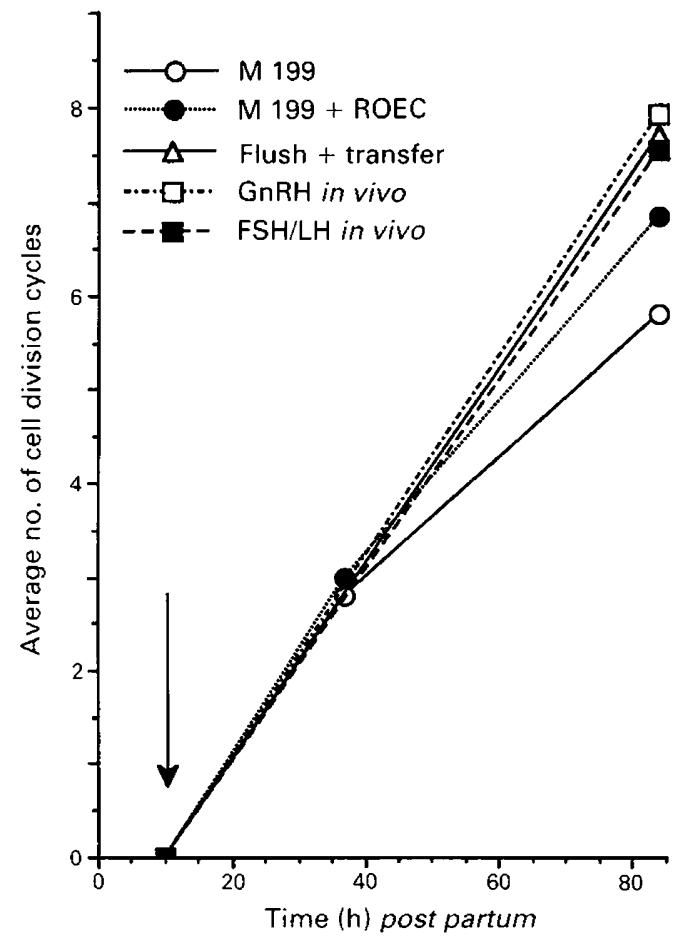

Fig. 3. Comparison of rabbit embryo development in vivo and in vitro for the average number of cell division cycles completed per embryo by $84 \mathrm{~h}$ after LH (GnRH). Data were derived by calculation of the log, base two, of embryo cell number. Ovulation is assumed to occur approximately $10 \mathrm{~h}$ after induction with $\mathrm{LH}$ or GnRH.

The percentage of cultured embryos reaching the blastocyst stage after $65 \mathrm{~h}$ ranged from 20 to $35 \%$ (Table 3). The 65-h time period was chosen to approximate the time embryos normally reside in the oviduct. When allowed an additional $24 \mathrm{~h}$ in vitro, $80-90 \%$ of the embryos formed blastocysts in both treatments (data not shown).

\section{Comparison of development in vivo and in vitro}

To gauge possible improvements in embryo culture, development of embryos cultured with oviduct epithelial cells was compared with that in vivo. Embryos flushed at $19 \mathrm{~h}$ after $\mathrm{LH}$ and transferred to pseudopregnant recipient oviducts were used because they originated from the same superovulated donors as the embryos which developed in vitro and were subjected to the same flushing and washing procedure. Embryos cultured in Medium 199 plus epithelial cells had more cells $(P<0.05)$ than did embryos cultured in Medium 199 alone, but embryos immediately transferred to oviducts were superior $(P<0.05)$ to embryos remaining in culture for most of the measures made (Table 3). Blastomere counts revealed that transferred embryos were approximately 1 cell cycle ahead of co-cultured embryos and 2 cell cycles ahead of embryos in medium alone (Fig. 3). The large deposition of mucin and the consequently increased volume of the embryo with its coverings contrasted sharply with the mucin-poor state of embryos in culture. Although the actual percentage of total blastocysts formed was higher in vivo than for either in vitro group, differences did not reach the selected level of statistical significance $(0.05<P<0 \cdot 10)$. 


\section{Discussion}

The purposes of this study were to partition superovulation effects, embryo recovery effects and culture effects on subsequent development of 1-cell rabbit embryos in vivo. This information was used to compare development in vitro after controlling for these effects. Although these two experimental procedures are commonly used by embryologists, the effects of these procedures appear to have been ignored or assumed to be innocuous. The establishment of control data which describe development up to the time embryos leave the oviduct and enter the uterus is especially important to anyone studying developmental requirements of preimplantation embryos in culture.

The first step taken was to collect data on a variety of measures for uninterrupted in-vivo development of oviducal-stage embryos obtained from GnRH-treated, artificially inseminated Dutch-Belted rabbits from our colony. These data (Table 2) agree very closely with those provided by other workers using naturally mated New Zealand White or cross-bred rabbits (Adams, 1958; Daniel, 1964; Alliston \& Pardee, 1973). Identically aged embryos developing in vivo in superovulated does were similarly evaluated and found to have significantly fewer cell numbers and smaller intrazonal volumes. Other measures were not affected. The reasons for this adverse effect of superovulation on development in vivo is not known.

Many workers have attempted to determine the normality of superovulated embryos (Maurer et al., 1968; Fujimoto et al., 1974; see Foote \& Ellington, 1988, for review). Fujimoto et al. (1974) noted an increased incidence of chromosomal abnormalities in rabbit blastocysts collected from does superovulated with PMSG and hCG. The abnormal embryos also had lower mitotic indices, but no obvious differences in the gross appearance of superovulated or control embryos were observed. Direct effects of superovulation were also noted in our study, in that intrazonal volumes were significantly reduced in embryos from both groups of superovulated donors in comparison to embryos from control donors receiving GnRH.

Superovulation may also affect embryos indirectly via its effects on the female reproductive tract. In the current study, cell numbers of embryos removed from superovulated donors at $19 \mathrm{~h}$ after LH (one-cell stage) and immediately transferred to non-superovulated recipients tended to be higher than in embryos residing continuously in superovulated does. In superovulated cattle, the incidence of abnormal embryos increases as the time interval between insemination and collection increases (Boland et al., 1978). One possibility is that superovulation accelerates embryo transport rate (Hawk, 1988), resulting in their premature arrival at the uterus. The deleterious effect of transferring oviducal-stage rabbit embryos to the uterus before their normal time of entry is a well documented phenomenon (Chang, 1950; Adams, 1979).

In general it appears that superovulation with $\mathrm{FSH} / \mathrm{LH}$ to produce rabbit embryos does have certain adverse effects on embryos, manifested by decreased embryo volumes and slower rates of cell division. Although these effects are not drastic, the data demonstrate that the developmental potential of embryos recovered from superovulated donors does differ from that of non-superovulated females. However, recovery of embryos from superovulated donors at an early stage of development minimizes these effects.

Embryo flushing also appeared to influence embryo development to a small degree. Deposition of mucin on flushed embryos returned immediately to the oviduct was significantly lower than in undisturbed embryos, even though the flushed embryos were only outside the oviduct an average of $35 \mathrm{~min}$. The kinetics of mucin secretion following ovulation are not well understood, but perhaps embryo flushing at $19 \mathrm{~h}$ after $\mathrm{LH}$ coincided with a period of maximal mucin release. Another possibility is that the surface of the embryo becomes less adherent to mucin after exposure to the polyvinyl alcohol in the flushing medium. Nevertheless, the smaller amount of mucin did not alter the rate of embryo development.

The reason for the lower recovery rate of embryos from does receiving embryos transferred surgically cannot be known with certainty. Whether some embryos were rapidly expelled into the 
peritoneal cavity or through the cervix could not be determined. The induction of anaesthesia and surgery in recipients $65 \mathrm{~h}$ earlier may have been contributing factors.

Fischer et al. (1988) have shown that the uptake of tritiated thymidine by 1-day-old rabbit embryos is significantly reduced by exposure for $60 \mathrm{~min}$ or more to visible light. Our results showed a slight, non-significant reduction in cell numbers in response to exposure to room conditions for 27-50 min. Embryo flushing and handling are therefore potentially deleterious to the 1-cell rabbit embryo, but significant damage can be avoided by minimizing handling time.

A clear benefit of co-culture with rabbit oviduct epithelial cells was observed when the rate of development in vitro was compared in the presence or absence of epithelial cells in primary culture (Table 3). None the less, co-cultured embryos were still inferior to embryos developed in vivo on the basis of several criteria evaluated, even after controlling for the effects of superovulation and flushing. This indicates that embryo culture conditions do not match the oviducal milieu in their ability to support embryo development.

Co-culture has been shown to improve in-vitro development in several species (reviewed by Rexroad, 1989), but more work is required to determine whether oviduct cells secrete specific embryotrophic factors or whether a non-specific feeder cell mechanism is operative. Other studies we have conducted (E. W. Carney, C. Tobback \& R. H. Foote, unpublished) indicate that coculture improves development of embryos compromised by culture in suboptimal media or other procedures, but that, in an improved medium, the effect of co-culture is less obvious.

In conclusion, these experiments provide new quantitative data for several measures which describe rabbit embryo development at the time of its entry into the uterus under natural and experimental conditions. Zygotes obtained from superovulated animals develop at a slower rate than embryos formed in non-superovulated controls, but this effect of superovulation can be minimized by early removal from the FSH-stimulated environment. Although we have demonstrated certain negative effects of superovulation and embryo flushing, it is clear that the major factor responsible for the developmental retardation observed in cultured rabbit embryos is the suboptimal nature of the culture conditions themselves.

This work was supported by a Multicenter Cooperative Program on Non-Human InVitro Fertilization and Preimplantation Development and was funded by the National Institute of Child Health and Human Development, NIH, through Cooperative Agreement HD21939. We thank C. Blanpain and M. Simkin for surgical and other technical assistance; Dr D. L. Black and V. Fairchild (University of Massachusetts, Amherst, MA) for providing details of collection and culture methods of rabbit oviducal epithelial cells; and Dr B. D. Bavister for suggestions on the manuscript. The LH was kindly provided by Vetrepharm and the Receptal by Hoechst-Roussel Agri-Vet Company.

\section{References}

Adams, C.E. (1958) Egg development in the rabbit: the influence of post-coital ligation of the uterine tube and of ovariectomy. J. Endocr. 16, 283-293

Adams, C.E. (1979) Consequences of accelerated ovum transport, including a re-evaluation of Estes' operation. J. Reprod. Fert. 55, 239-246.

Alliston, C.W. \& Pardee, N.R. (1973) Variability of embryonic development in the rabbit at 19 to 168 hours after mating. Lab. Anim. Sci. 23, 665-670.

Binkerd, P.E. \& Anderson, G.B. (1979) Transfer of cultured rabbit embryos. Gamete Res. 2, 65-73.

Black, D.L., Fairchild, V., Hyde, B., Clark, G. \& Overstrom, E. (1985) Rabbit oviduct epithelial cells in culture. Biol. Reprod. 32, Suppl. 1, p. 363, abstr.
Boland, M.P., Crosby, T.F. \& Gordon, I. (1978) Morphological normality of cattle embryos following superovulation using PMSG. Theriogenology 10, 175-180.

Chang, M.C. (1950) Development and fate of transferred rabbit ova or blastocysts in relation to the ovulatory time of recipients. J. exp. Zool. 114, 197-216.

Daniel, J.C., Jr (1964) Early growth of rabbit trophoblast. Am. Nat. 98, 85-96.

Fairchild, V.M. (1987) Primary culture of rabbit oviduct epithelium. M.S. thesis, University of Massachusetts, Amherst.

Fischer, B. (1987) Development retardation in cultured preimplantation rabbit embryos. J. Reprod. Fert. 79, $115-123$. 
Fischer, B., Schumacher, A., Hegele-Hartung, C. \& Beier, H.M. (1988) Potential risk of light and room temperature exposure to preimplantation embryos. Fert. Steril. 50, 938-944.

Foote, R.H. \& Ellington, J.E. (1988) Is a superovulated oocyte normal? Theriogenology 29, 111-123.

Fujimoto, S., Pahlavan, N. \& Dukelow, W. R. (1974) Chromosome abnormalities in rabbit preimplantation blastocysts induced by superovulation. $J$. Reprod. Fert. 40, 177-181.

Hawk, H.W. (1988) Gamete transport in the superovulated cow. Theriogenology 29, 125-142.

Hodgson, B.J. \& Pauerstein, C.J. (1976) Comparison of oviducta! transport of fertilized and unfertilized ova after HCG or coitus induced ovulation in rabbits. Biol. Reprod. 14, 377-380.

Kane, M.T. (1987) In vitro growth of preimplantation rabbit embryos. In The Mammalian Preimplantation Embryo: Regulation of Growth and Differentiation in Vitro, pp. 193-218. Ed. B. D. Bavister. Plenum Press, New York.

Kennelly, J.J. \& Foote, R.H. (1965) Superovulatory response to pre- and post-pubertal rabbits to com- mercially available gonadotrophins. J. Reprod. Fert. 9, 177-188.

Mauer, R.R., Hunt, W.L., Van Vleck, L.D. \& Foote, R.H. (1968) Developmental potential of superovulated rabbit ova. J. Reprod. Fert. 15, 171-175.

Pursel, V.G., Wall, R.J., Rexroad, C.E., Jr, Hammer, R.E. \& Brinster, R.L. (1985) A rapid whole-mount staining procedure for nuclei of mammalian embryos. Theriogenology 24, 687-700.

Rexroad, C.E., Jr (1989) Co-culture of domestic animal embryos. Theriogenology 31, 105-114.

Seidel, G.E., Jr, Bowen, R.A. \& Kane, M.T. (1976) In vitro fertilization, culture, and transfer of rabbit ova. Fert. Steril. 27, 861-870.

Snedecor, G.W. \& Cochran, W.G. (1980) Statistical Methods. Iowa State University Press, Ames, Iowa.

Zar, J.H. (1984) Biostatistical Analysis. Prentice-Hall, Englewood Cliffs, New Jersey.

Received 10 October 1989 